\title{
PERSEPSI PESRTA DIDIK DAN GURU IPA TERHADAP PENGGUNAAN GAME EDUKASI
}

\author{
Assa Prima Sekarini \\ Universitas Negeri Semarang \\ e-mail: assa.prima13@gmail.com
}

\begin{abstract}
Abstrak
Penelitian ini bertujuan untuk mengetahui persepsi pesrta didik dan guru IPA terhadap penggunaan game edukasi. Metode penelitian yang digunakan adalah deskriptif kuantitatif dengan subjek penelitian adalah guru IPA dan pesrta didik kelas VII dan IX tahun ajaran 2018/2019. Instrumen penelitian yang digunakan adalah lembar angket dan lembar wawancara. Hasil penelitian menunjukkan bahwa ketertarikan pesrta didik pada penggunaan game edukasi dalam proses pembelajaran adalah $81,9 \%$. Kesimpulan dari penelitian ini adalah persepsi pesrta didik dan guru terhadap game edukasi termasuk dalam kategori baik, karena respon mereka terhadap penggunaan game edukasi baik dan antusias. Manfaat penelitian ini dapat digunakan sebagai studi pendahuluan untuk melakukan penelitian lebih lanjut tentang penggunaan game edukasi dalam proses pembelajaran.

Kata kunci: Persepsi, Game Edukasi, IPA
\end{abstract}

\section{Abstract}

The purpose of this study was to determine the perceptions of students and science teachers on the use of educational games. The research method used was descriptive quantitative with the research subjects being science teachers and students of grades VII and IX in the academic year 2018/2019. The research instruments used were questionnaire sheets and interview sheets. The results showed that students' interest in the use of educational games in the learning process was $81.9 \%$. The conclusion of this study is that the perceptions of students and teachers on educational games are included in the good category, because of their response to the use of good and enthusiastic educational games. The benefits of this study can beused as a preliminary study to conduct further research on the use of educational games in the learning process.

Keywords: Perception, Educational Games, Science

\section{PENDAHULUAN}

Representasi tentang game digital sering dianggap negatif oleh sebagian besar orang (Whitton \& Maclure, 2017). Beberapa dekade terakhir ini, semakin banyak remaja usia sekolah dengan mudah berselancar di Internet dan sering bermain game online secara berlebihan (Pan et al., 2018). Intensitas bermain game yang tinggi dapat membuat pesrta didik mengalami kecanduan sehingga membuatnya tidak memiliki skala prioritas dalam beraktivitas sehari-hari, mendorong individu untuk bertindak asosial dan menyebabkan individu malas belajar sehingga berdampak pada nilai akademiknya (Kurniawan, 2017), serta mudah untuk melakukan prokrastinasi yakni kebiasaan menunda suatu kegiatan penting dan tidak membuat tugas secara tepat waktu (Knaus, 2010). 
Game dapat berdampak positif terhadap perkembangan akademik pesrta didik jika dimanfaatkan dalam proses pembelajaran melalui game edukasi. Game edukasi merupakan sebuah media penghubung antara pendidikan dan hiburan yang memiliki konten dan berfokus pada aktivitas belajar pesrta didik (Hamari, et al., 2016). Ketersediaan aplikasi game sebagai media pembelajaran yang menarik, mudah digunakan, dan berguna untuk meningkatkan hasil belajar pesrta didik (Adnan, Prasetyo, \& Nuriman, 2017).

Hasil penelitian Morsi \& Jackson, (2007) menunjukkan bahwa sebagian besar pesrta didik berpendapat bahwa mereka merasakan perasaan yang positif seperti senang dan tertarik pada saat bermain game. Putra \& lqbal, (2016) menambahkan bahwa pesrta didik akan lebih optimal dalam pembelajaran ketika diberikan game dan modul yang berorientasi pada lingkungan sekitar. Hal ini tentunya dapat menjadi salah satu alternatif untuk mengurangi pembelajaran yang hanya berpusat pada guru, selain itu guru tidak hanya mengandalkan buku pegangan mengajar (Indayatmi, 2018).

Game dapat dimanfaatkan untuk membantu proses pembelajaran. Penelitian Morsi \& Jacson (2007) menunjukkan bahwa sebagian besar pesrta didik berpendapat bahwa mereka merasakan perasaan yang positif seperti senang dan tertarik pada saat bermain game. Sementara penelitian Putra \& lqbal (2016) menyebutkan bahwa pesrta didik akan lebih optimal dalam pembelajaran ketika diberikan game dan modul yang berorientasi pada lingkungan sekitar. Hal ini tentunya dapat menjadi salah satu alternatif untuk mengurangi pembelajaran yang hanya berpusat pada guru, selain itu guru tidak hanya mengandalkan buku pegangan mengajar (Indayatmi, 2018). Guru dapat memanfaatkan sebuah game edukasi sebagai media pembelajaran. Game edukasi merupakan salah satu jenis game yang dapat dimainkan pada berbagai peralatan digital, seperti komputer dan mobile (All, Nuñez Castellar, \& Van Looy, 2016). Namun, keengganan guru untuk memanfaatkan sumber-sumber belajar digital, kurangnya kreativitas dan minat untuk berinovasi mengindikasikan bahwa guru masih belum memiliki motivasi yang tinggi (Dopo \& Ismaniati, 2016).

Dalam proses pembelajaran diperlukan efektivitas suatu media yang digunakan, termasuk game edukasi. Efektivitas dari game edukasi sebagai media pembelajaran, tentunya sangat bergantung pada persepsi pesrta didik dan guru. Oleh karena itu, perlu dilakukan penelitian untuk mengetahui persepsi pesrta didik dan guru IPA SMP terhadap game edukasi dan sejauh mana minat belajar pesrta didik apabila guru memanfaatkan game edukasi dalam proses pembelajarannya.

\section{METODE}

Penelitian ini menggunakan pendekatan deskriptif kuantitatif. Indikator persepsi dalam penelitian ini meliputi (1) ketertarikan pada game edukasi, (2) persepsi tentang game, 
dan (3) ketertarikan pada jenis game. Subjek penelitian adalah Guru IPA dan pesrta didik kelas VII dan IX tahun ajaran 2018/2019. Teknik pengambilan data dalam penelitian ini menggunakan metode angket dan wawancara. Angket digunakan untuk mengetahui persepsi pesrta didik terhadap game edukasi, sedangkan wawancara digunakan untuk mengetahui pendapat guru IPA tentang game edukasi. Pengambilan sampel penelitian dilakukan di 2 Sekolah. Analisis deskriptif kuantitatif dilakukan untuk menganalisis persepsi pesrta didik terhadap game edukasi, yang mengacu pada tabel kategori persentase.

Tabel 1. Kategori Persentase (Dopo \& Ismaniati, 2016)

\begin{tabular}{ll}
\hline \multicolumn{1}{c}{ Kategori } & \multicolumn{1}{c}{ Persentase } \\
\hline Baik & $76 \%-100 \%$ \\
Cukup & $56 \%-75 \%$ \\
Kurang Baik & $40 \%-55 \%$ \\
Tidak Baik & Kurang dari 40\% \\
\hline
\end{tabular}

\section{HASIL DAN PEMBAHASAN}

Hasil analisis persepsi pesrta didik terhadap game edukasi, menunjukkan bahwa ketertarikan pesrta didik untuk menggunakan game edukasi dalam pembelajaran IPA berada dalam kategori baik dengan persentase $81,9 \%$. Pesrta didik juga berpendapat bahwa game mampu menambah wawasan terutama pada bidang teknologi, hal ini ditunjukkan pada perolehan persentase $80,8 \%$ dalam kategori baik. Jenis game edukasi yang paling diminati oleh pesrta didik adalah jenis petualangan (adventure), hal ini ditunjukkan pada perolehan persentase $83,7 \%$ dalam kategori baik. Data persepsi guru terhadap game edukasi ditunjukkan pada Tabel 2. 
Tabel 2. Analisis persepsi responden guru terhadap game edukasi

\begin{tabular}{|c|c|c|c|}
\hline No. & Aspek & Narasumber 1 & Narasumber 2 \\
\hline 1 & Teknologi pendidikan & $\begin{array}{l}\text { Teknologi pada masa sekarang } \\
\text { sangat pesat dan membantu } \\
\text { terutama dalam pendidikan } \\
\text { untuk membuat media } \\
\text { pembelajaran pada saat KBM. }\end{array}$ & $\begin{array}{l}\text { Teknologi dalam pendidikan } \\
\text { digunakan sebagai alat } \\
\text { bantu yang nantinya } \\
\text { diharapkan mampu } \\
\text { meningkatkan pemahaman } \\
\text { pesrta didik. Teknologi yang } \\
\text { digunakan sebagai media } \\
\text { pembelajaran disesuaikan } \\
\text { dengan tujuan } \\
\text { pembelajaran. }\end{array}$ \\
\hline 2 & $\begin{array}{l}\text { Pemanfaatan teknologi } \\
\text { dalam pembelajaran } \\
\text { IPA }\end{array}$ & $\begin{array}{l}\text { Penggunaan komputer, power } \\
\text { point, bahan ajar dalam bentuk } \\
\text { e-learning, video ajar, dsb. } \\
\text { - Keuntungan yang diperoleh: } \\
\text { memberikan kemudahan bagi } \\
\text { guru untuk menyampaikan } \\
\text { materi kepada pesrta didik. }\end{array}$ & $\begin{array}{l}\text { Penggunaan media power } \\
\text { point untuk menyampaikan } \\
\text { materi. } \\
\text { - Keuntungan yang diperoleh: } \\
\text { materi yang disampaikan } \\
\text { oleh guru mudah diterima } \\
\text { pesrta didik, membuat } \\
\text { pesrta didik lebih tertarik } \\
\text { mengikuti pembelajaran. }\end{array}$ \\
\hline 3 & Game edukasi & $\begin{array}{l}\text { Pernah membuat game edukasi } \\
\text { sendiri, dengan } \\
\text { mengembangkan aplikasi } \\
\text { Kahoot. } \\
\text { - Kahoot merupakan suatu } \\
\text { aplikasi penilaian dalam } \\
\text { pembelajaran, sehingga pesrta } \\
\text { didik dapat langsung menjawab } \\
\text { pertanyaan dan mengetahui } \\
\text { nilainya secara langsung. }\end{array}$ & $\begin{array}{l}\text { Pembelajaran yang } \\
\text { menerapkan game edukasi } \\
\text { diperlukan persiapan yang } \\
\text { matang supaya proses } \\
\text { pembelajaran berlangsung } \\
\text { kondusif. }\end{array}$ \\
\hline 4 & Manfaat game edukasi & $\begin{array}{l}\text { Meningkatkan motivasi dan hasil } \\
\text { belajar pesrta didik. }\end{array}$ & $\begin{array}{l}\text { Meningkatkan keaktifan } \\
\text { pesrta didik, membuat } \\
\text { pesrta didik lebih tertarik dan } \\
\text { senang, meningkatkan } \\
\text { pemahaman pesrta didik. }\end{array}$ \\
\hline
\end{tabular}

Hasil analisis persepsi guru terhadap game edukasi, menunjukkan bahwa guru telah memahami tentang perkembangan teknologi pada masa sekarang yang sangat pesat, tak terkecuali pada bidang pendidikan. Teknologi pendidikan hakikatnya merupakan penerapan dari pengetahuan yang sudah terorganisir sebagai suatu produk dan proses dalam mengatasi masalah belajar pesrta didik (Dopo \& Ismaniati, 2016). Teknologi dalam bidang pendidikan seringkali dimanfaatkan sebagai media pembelajaran untuk membantu guru dalam menyampaikan materi pada pesrta didik. Kedua narasumber tersebut mengatakan bahwa game edukasi memiliki banyak manfaat, salah satunya mampu meningkatkan motivasi belajar pesrta didik sehingga memudahkan guru dalam menyampaikan materi pada proses pembelajaran.

Persepsi guru dan pesrta didik terhadap game edukasi, memiliki peranan penting dalam mengetahui minat terhadap game edukasi dan sejauh mana pengetahuan tentang edukasi yang sudah dimiliki. Berdasarkan hasil penelitian, diketahui bahwa persepsi pesrta 
didik terhadap game edukasi termasuk dalam kategori baik. Hal ini sesuai dengan penelitian yang dilakukan oleh Ibrahim, et al., (2011) mengenai persepsi pesrta didik tentang penggunaan game edukasi pada proses pembelajaran (Ibrahim, et al., 2011). Hasil penelitian tersebut menunjukkan bahwa persepsi pesrta didik terhadap penggunaan game edukasi online tinggi, hal ini ini ditunjukkan dengan hasil pendapat mereka yang menyatakan bahwa pembelajaran dengan game edukasi sangat menyenangkan. Mereka juga tertarik untuk menggunakan game edukasi dalam pembelajaran. Hal ini sesuai dengan pernyataan bahwa pesrta didik merasa lebih menikmati dan termotivasi dalam belajar ketika menggunakan media digital atau video game (Arkün Kocadere \& Çağlar, 2015).

Berdasarkan hasil wawancara, guru menyebutkan bahwa game edukasi sangat bermanfaat untuk diterapkan karena dapat memotivasi pesrta didik untuk belajar sehingga prestasi akademik pesrta didik dapat meningkat. Penggunaan game edukasi dalam kegiatan pembelajaran sudah tidak diragukan lagi, karena game edukasi sangat berguna bagi pesrta didik untuk mengembangkan keterampilan, meningkatkan persepsi dan stimulus, serta mampu mengembangkan kemampuan dalam menyelesaikan masalah (de Aguilera \& Mendiz, 2003). Akan tetapi, ada beberapa kendala yang ditemukan, antara lain: (1) tidak semua sekolah bisa menerapkan game edukasi, karena tergantung pada sarana dan prasarana yang memadai di sekolah tersebut; (2) guru harus menyediakan waktu luang untuk membuat game edukasi tersebut. Penyusunan game pembelajaran tentunya memerlukan waktu yang cukup lama, sehingga guru dapat menggunakan game edukasi yang sudah dikembangkan (Li \& Tsai, 2013).

\section{SIMPULAN}

Guru dan pesrta didik sama-sama memiliki daya minat yang tinggi terhadap penggunaan game edukasi. Hal ini berdasarkan hasil angket respon pesrta didik tentang ketertarikan dan persepsi menggunakan game edukasi pada pembelajaran IPA dalam kategori baik. Sedangkan jenis game yang paling diminati adalah yang mengandung unsur petualangan (adventure). Begitu halnya dengan respon guru ketika dilakukan wawancara, menunjukkan bahwa guru memiliki ketertarikan pada game edukasi karena memiliki manfaat dalam proses pembelajaran, yakni memudahkan guru dalam menyampaikan suatu materi, karena game edukasi mampu mendorong minat pesrta didik dalam mengikuti proses pembelajaran, sehingga diharapkan dapat meningkatkan hasil belajar pesrta didik.

\section{DAFTAR PUSTAKA}

Adnan, F., Prasetyo B., Nuriman N. 2017. Usability testing analysis on the Bana game as education game design references on junior high school. Jurnal Pendidikan IPA Indonesia, 6 (1): 88-94. 
All, A., Nuñez Castellar E.P., Van Looy J. 2016. Assessing the effectiveness of digital gamebased learning: Best practices. Computers and Education. 92-93, 90-103.

Arkün Kocadere S., Çağlar Ş. The Design and Implementation of a Gamified Assessment. Journal of E-Learning and Knowledge Society, 11 (3): 85-99.

de Aguilera M., Mendiz A. 2003. Video games and education: Education in the Face of a "Parallel School." ACM Computers in Entertainment, 1 (1): 1-14.

Dopo, F. B., Ismaniati C. 2016. Persepsi Guru tentang Digital Natives, Sumber Belajar Digital dan Motivasi Memanfaatkan Sumber Belajar Digital. Jurnal Inovasi Teknologi Pendidikan. 3 (1): 13-24.

Hamari, J., Shernoff D. J., Rowe E., Coller B., Asbell-Clarke J., Edwards T. 2016. Challenging games help students learn: An empirical study on engagement, flow and immersion in game-based learning. Computers in Human Behavior, 54: 170-179. 045.

Ibrahim, R., Wahab S., Yusoff R. C. Mohd., Khalil K., Jaafar A. 2011. Student Perceptions of Educational Games in Higher Education: An Empirical Study. Issues in Information Systems, 12 (1): 120-133.

Indayatmi. 2018. Pengaruh Vlog Pembelajaran terhadap Peningkatan Hasil Belajar Peserta Didik SMK Negeri 2 Depok. Jurnal Pendidikan Sains, 6 (1): 56-63.

Knaus, W. 2010. End Procrastination Now!: Get it Done with a Oroven Psychological Approach. United States: McGraw Hill Professional.

Kurniawan D. E. 2017. Pengaruh Intensitas Bermain Game Online terhadap Perilaku Prokrastinasi Akademik Pada Mahapesrta didik Bimbingan dan Konseling Universitas PGRI Yogyakarta. Jurnal Konseling Gusjigang, 3 (1): 1-8.

Li, M.-C., Tsai C-C. 2013. Game-Based Learning in Science Education: A Review of Relevant Research. Journal of Science Education and Technology, 22 (6): 877-898.

Morsi, R., Jackson E. 2007. Playing and learning? Educational gaming for engineering education. Proceedings - Frontiers in Education Conference, FIE, 10-13; 1-6.

Pan, N., Yang Y., Du X., Qi X., Du G., Zhang Y., Zhang Q. 2018. Brain structures associated with internet addiction tendency in adolescent online game players. Frontiers in Psychiatry, 9 (MAR).

Whitton, N., Maclure M. 2017. Video game discourses and implications for game-based education. Discourse, 38 (4): 561-572. 